\title{
Serum and Urinary C-Reactive Protein Concentrations in Dogs with Leptospirosis*
}

\author{
Concentrações de proteína C-reativa sérica e urinária em cães com leptospirose
}

\author{
Simone Tostes Oliveira', Joanne Belle Messick², Alexander Welker Biondo ${ }^{3}$, Andrea Pires Santos'², Ana Márcia \\ de Sá Guimarães², Ahmed Sidi Mohamed², José Antônio Simões Pires Neto ${ }^{4}$, Magnus Larruscaim \\ Dalmolin' \& Félix Hilario Diaz González'
}

\begin{abstract}
Background: Leptospirosis is a bacterial disease caused by pathogenic strains of Leptospira, which may affect human beings and a wide range of both domestic and wild animals. The disease in dogs is still a challenge for clinicians, since definitive diagnosis may be reached only few days after overt clinical signs. Besides that, dogs with leptospiruria have zoonotic risk, making development of rapid screening tests crucial for early diagnosis of disease. C-reactive protein is a positive acute phase protein, and in the dog a strong and fast response is expected after any tissue injury. The aim of this study was to evaluate serum and urinary C-reactive protein as potential early indicators of leptospirosis in dogs, and its association with clinical serum biochemistry, complete blood count (CBC) and clinical outcome.

Materials, Methods \& Results: A total of 62 dogs with risk factors and/or clinical signs of leptospirosis were prospectively obtained and included in this study. Definitive diagnosis was based on serology, using the microscopic agglutination test (MAT) against 13 serovars, and on a specific polymerase chain reaction (PCR) in blood or urine, using the primers sets G1/G2 and B64I/B64II, which amplify DNA of pathogenic leptospires. Clinical serum biochemistry included creatinine, urea, alanine aminotransferase, alkaline phosphatase, creatine kinase and albumin. C-reactive protein was performed in serum and urine using a semi-quantitative latex-agglutination test. A total of 49/62 (79\%) dogs had a positive diagnosis of leptospirosis. From these, 12 (24.5\%) had positive blood PCR, 17 (34.7\%) positive urine PCR and 43 (87.7\%) had positive serology. Concurrent positive serology and positive PCR (blood or urine) occurred in 19 (38.8\%) dogs, whereas 24 (49\%) dogs had positive serology only, and $6(12.2 \%)$ dogs had positive PCR only. Dogs with negative results at serology and PCR were kept for analysis and participated as negative control group. Out of the $62 \mathrm{dogs}, 25(40.3 \%)$ had high liver enzymes, 18 (29\%) had azotemia, 23 (37.1\%) had leukocytosis, 37 (59.7\%) had high creatine kinase levels and 37 (59.7\%) had hypoalbuminemia. Twelve death cases $(19.3 \%)$ occurred within 10 days after the sample collection. Positive serology was significantly associated with urinary $\mathrm{C}$-reactive protein $(P=0.038)$. Only a weak association was found between serum C-reactive protein and blood PCR (area under curve $=0.68$ ). There was no association between urinary $C$-reactive protein and urine $\mathrm{PCR}$, urinary $\mathrm{C}$-reactive protein and blood PCR, serum C-reactive protein and positive serology, or serum C-reactive protein and urine PCR. Increased liver enzymes $(P=0.04)$ and hypoalbuminemia $(P=0.002)$ were associated with high levels of serum $C$-reactive protein. There was no association between serum or urinary $C$-reactive protein and death.

Discussion: In this study, it was hypothesized that increased blood C-RP may be expected in dogs having leptospiremia, whereas increased urinary C-RP may be expected in dogs having leptospiruria. However, the results showed that C-reactive protein was not useful to predict leptospiremia or leptospiruria in the naturally infected dogs of this study; and although association between urinary C-reactive protein and seropositivity was observed, it should not be used as a unique test for leptospirosis. In conclusion, although C-reactive protein may be used as part of a screening profile, it should not be considared as indicator alone of leptospirosis screening in dogs.
\end{abstract}

Keywords: dog, leptospirosis, diagnosis, serology, PCR, screening, C-reactive protein.

Descritores: cão, leptospirose, diagnóstico, sorologia, PCR, triagem, proteína C-reativa.

Received: October 2009

www.ufrgs.br/actavet

Accepted: January 2010

*Article based on a Dissertation submitted by the senior author in partial fulfillment of requirements for the degree of Doctor in Veterinary Sciences, Post Graduate Program in Veterinary Sciences (PPGCV), Universidade Federal do Rio Grande do Sul (UFRGS), Porto Alegre, RS, Brazil. Study was partially sponsored by a National Council of Technological and Scientific Development (CNPq) Grant. ${ }^{1}$ Department of Veterinary Clinical Pathology, Faculdade de Veterinária (FaVet)-UFRGS, Av. Bento Gonçalves No. 9090, CEP 91540-000 Porto Alegre, RS, Brazil. ${ }^{2}$ Department of Comparative Pathobiology, Purdue University, West Lafayette, IN, USA. ${ }^{3}$ Department of Veterinary Medicine, Universidade Federal do Paraná (UFPR), PR, Brazil and Department of Veterinary Pathobiology, University of Illinois (UIUC), IL, USA. ${ }^{4}$ Instituto de Pesquisas Veterinárias Desidério Finamor (IPVDF), Eldorado do Sul, RS, Brazil. CORRESPONDENCE: S.T. Oliveira [tostesimone@yahoo.com.br - FAX: +55 (51) 3308 7305]. 


\section{INTRODUCTION}

Leptospirosis is a zoonotic disease caused by spirochetes of the genus Leptospira. The disease is biphasic, with a phase of septicemia in the first week (leptospiremia), followed by a second phase of antibody production and initiation of Leptospira shedding into urine (leptospiruria) [2]. The infection in dogs does not always result in overt clinical signs [11], being dependent on the organism virulence and host susceptibility [8]. Definitive diagnosis is based on detection of serum antibodies (serology) or detection of leptospires in clinical material (molecular techniques and/or organism culture/isolation) [11].

C-reactive protein (C-RP) is a positive acute phase protein (APP) produced in hepatocytes (although human renal cortical tubular epithelial cells are also able to produce $\mathrm{C}-\mathrm{RP}$ ) and released into the bloodstream as consequence of inflammatory or infectious processes [7]. APPs have a rapid serum production and clearance, mostly reflecting the dog status at the time of sampling. Therefore, APPs may be useful to provide evidence of acute inflammatory or infectious disease, even with no evident clinical signs; however, it should not be used as a primary diagnostic test due to its poor specificity [4].

The aim of this study was to verify the use-fulness of C-reactive protein (C-RP) levels in serum and urine as an early indicator of leptospirosis in dogs. In addition, we investigated the possible association between C-RP and clinical serum biochemistry, complete blood count (CBC) and clinical outcome in these dogs.

\section{MATERIALSAND METHODS}

Dogs from either the Veterinary Teaching Hospital (Federal University of Rio Grande do Sul) or the Control Center of Zoonoses in Porto Alegre, Brazil were screened, evaluated (between August of 2007 and February of 2008) and included in the present study. Dogs should have risk factors (history of rats and/or lacking of vaccination associated with outdoor access) and/or clinical signs (icterus, anorexia/weight loss, vomiting, diarrhea, polyuria/polydispsia and fever) of leptos-pirosis, with no history of antibiotic treatment. Definitive diagnosis was confirmed by either serology titer $\geq 1: 100$ for any of the tested serovars, or positive PCR in blood or urine. Dogs with negative results were kept for analysis and participated as negative control group. The present study has been submitted and approved by the University Ethics Committee, following ethical principles for animal experimentation of the Brazilian College of Animal Experimentation (COBEA).

Serology was performed using the Microscopic Agglutination Test (MAT) under standard protocol, and tested against the following serovars: australis, autumnalis, bratislava, canicola, copenhageni, grippotyphosa, hardjo, hebdomadis, icterohaemorrhagiae, pomona, pyrogenes, tarassovi and wolffi. Titers $\geq 1: 100$ were considered positives.

Blood DNA was extracted using the QIAamp DNA Blood Mini kit ${ }^{1}$. Urine DNA extraction was performed using a modified protocol [9]. Briefly, PBS ( $\mathrm{pH} 7.4$ ) was added to urine in a 1:2.5 v/v proportion to neutralize the sample immediately after collection. Urine DNA extraction was performed in duplicate. A total of $1.5 \mathrm{~mL}$ of the sample was incubated at $37^{\circ} \mathrm{C}$ for 10 minutes, and then centrifuged at $800 \times \mathrm{g}$ at room temperature. The supernatant was centrifuged at $1560 \times \mathrm{g}$ for 20 minutes. The resultant supernatant was discharged; pellet was resuspended and washed with $1 \mathrm{~mL}$ of PBS, and then centrifuged at $1560 \times \mathrm{g}$ for an additional 20 minutes. The supernatant was discharged and the pellet was resuspended in $100 \mu \mathrm{L}$ of PBS and boiled for 10 minutes. DNA was stored at $20^{\circ} \mathrm{C}$ until molecular analysis.

The primer sets G1/G2 and B64-I/B64II [5] were used to amplify DNA from pathogenic leptos-pires in blood (leptospiremia) and urine (leptospi-ruria). PCR reactions were carried out in $1 \times$ buffer, $1.5 \mathrm{mM} \mathrm{MgCl}_{2}$, $2.5 \mathrm{mM}$ of each nucleotide (dATP, dCTP, dGTP and dTTP), 5 pmol of each primer, 1.25 U of "GoTaqFlexi DNA Polymerase", $5 \mu \mathrm{L}$ of the DNA template and ultrapure water up to $25 \mu \mathrm{L}$. A positive control and two negatives controls were included in each run. The thermocycler conditions consisted of an initial step at $95^{\circ} \mathrm{C}$ for 2 minutes, followed by 40 cycles of denaturation at $94^{\circ} \mathrm{C}$ for 1 minute, annealing at $55^{\circ} \mathrm{C}$ for 45 seconds and extension at $72^{\circ} \mathrm{C}$ for 45 seconds, and a final ex-tension at $72^{\circ} \mathrm{C}$ for 5 minutes. Electrophoresis $(1 \mathrm{~h}$ at $100 \mathrm{~V})$ was performed with $15 \mu \mathrm{L}$ of the reaction solution in a $1.5 \%$ agarose gel with ethidium bromide. PCR products were visualized under UV light and photographed.

C-RP analysis was performed in serum and fresh urine supernatant (with no additive) using the semiquantitative latex-agglutination test "Human $G M B H$ ", previous validated for use in canine serum [12]. Results are reported as an approximate $\mathrm{mg} / \mathrm{L}$ concentration of C-RP. Sensitivity of detection was $6 \mathrm{mg} / \mathrm{L}$. 
Clinical serum biochemistry was performed by spectrophotometry in a semi-automatic analyzer (Metrolab $\left.1600^{4}\right)$ using Labtest ${ }^{5}$ commercial kits, and included creatinine, urea, alanine aminotransferase, alkaline phosphatase, creatine kinase and albumin. Complete Blood Count (CBC) was performed in EDTA blood using a Celm CC 530 semiautomatic cell counter.

Chi-square test or Fisher's exact test (when appropriate) were used to investigate the association between both serum and urine C-RP and blood and urine PCRs, serology, liver enzymes, azotemia, leukocytes count, creatine kinase and albumin concentrations, and animal's death. Receiver operator curve (ROC) was also plotted for serum and urine C-RP using blood and urine PCRs as a reference test. A $P$-value $<0.05$ was considered significant. Stata 11 (StataCorp, College Station, TX) was used for the analysis.

\section{RESULTS}

Sixty-two dogs were preliminary screened and evaluated. A total of 49/62 (79\%) dogs were positive for leptospirosis based on serology and/or PCR. From these, 12 (24.5\%) had positive blood PCR, 17 (34.7\%) positive urine PCR and $43(87.7 \%)$ had positive serology. Concurrent positive serology and positive PCR (blood or urine) occurred in 19 (38.8\%) dogs, whereas 24 (49\%) dogs had positive serology only, and $6(12.2 \%)$ dogs had positive PCR only. Out of the 62 dogs, 25 (40.3\%) had high liver enzymes, 18 (29\%) had azotemia, $23(37.1 \%)$ had leukocytosis, 37 (59.7\%) had high creatine kinase levels and 37 (59.7\%) had hypoalbuminemia. Twelve death cases $(19.3 \%)$ occurred within 10 days after the sample collection.

Serum and urinary C-RP concentrations in dogs with leptospirosis and in negative dogs are shown in Table 1. Positive serology was associated with urinary $\mathrm{C}-\mathrm{RP}(\mathrm{P}=0.038)$, but not with serum $\mathrm{C}-\mathrm{RP}$. There was a weak association between serum C-RP and blood PCR (Figure 1) whereas no association was found between serum C-RP and urine PCR; between urinary $\mathrm{C}-\mathrm{RP}$ and blood PCR; or between urinary C-RP and urine PCR. Increased liver enzymes $(P=0.04)$ and

Table 1. Serum and urinary C-reactive protein concentrations in 62 dogs with or without leptospirosis, diagnosed by MAT and PCR in blood and urine.

\begin{tabular}{|c|c|c|c|c|c|c|c|}
\hline \multirow{3}{*}{ Diagnosis of leptospirosis } & \multirow{3}{*}{ n. of dogs } & \multicolumn{3}{|c|}{ Serum C-reative protein } & \multicolumn{3}{|c|}{ Urinary C-reactive protein } \\
\hline & & \multicolumn{2}{|c|}{$(\mathrm{mg} / \mathrm{L})$} & \multirow{2}{*}{$\begin{array}{l}\text { n. of dogs with } \\
\text { C-RP }>6\end{array}$} & \multicolumn{2}{|c|}{$(\mathrm{mg} / \mathrm{L})$} & \multirow{2}{*}{$\begin{array}{l}\text { n. of dogs with } \\
\text { C-RP }>6\end{array}$} \\
\hline & & Mean & Range & & Mean & Range & \\
\hline \multicolumn{8}{|l|}{ Serology } \\
\hline Positive & 43 & 84 & $<6-384$ & 39 & 13 & $<6-96$ & 11 \\
\hline Negative & 19 & 133 & $<6-384$ & 17 & 34 & $<6-192$ & 7 \\
\hline \multicolumn{8}{|l|}{ Blood PCR (leptospiremia) } \\
\hline Positive & 12 & 143 & $12-384$ & 12 & 29 & $<6-192$ & 4 \\
\hline Negative & 50 & 89 & $<6-384$ & 44 & 17 & $<6-192$ & 14 \\
\hline \multicolumn{8}{|l|}{ Urinary PCR (leptospiruria) } \\
\hline Positive & 17 & 69 & $<6-384$ & 15 & 18 & $<6-192$ & 3 \\
\hline Negative & 45 & 111 & $<6-384$ & 41 & 29 & $<6-192$ & 15 \\
\hline \multicolumn{8}{|l|}{ All methods together* } \\
\hline Positive & 49 & 96 & $<6-384$ & 44 & 19 & $<6-192$ & 13 \\
\hline Negative & 13 & 112 & $<6-384$ & 12 & 20 & $<6-192$ & 5 \\
\hline
\end{tabular}

\footnotetext{
* Considering all dogs diagnosed, including concurrent positive results and dogs with only one positive result (serology or blood PCR or urine PCR).
} 
hypoalbuminemia $(P=0.002)$ were significantly associated with serum C-RP (data not shown).

\section{DISCUSSION}

Higher concentrations of C-RP were reported in infectious diseases when compared to other causes, despite of its non-specificity [13]. Therefore, increased blood C-RP may be expected in dogs with leptospiremia, and increased urinary C-RP may be expected in leptospiruria. However, our results have shown that serum C-RP was unable to predict leptospiremia, and no relationship between urine PCR and urinary C-RP was found. Although associations between serology and urinary C-RP levels were observed, and the test may be included in a diagnostic screening profile, our data suggest that serum and urinary C-RP should not be used as screening test alone for leptospirosis in naturally infected dogs.

In the present study, association between serum C-RP and serology was not observed, and the association of urinary C-RP with serology does not justify its use, since the urinary C-RP test did not detect dogs with leptospiremia or leptospiruria. Interestingly, previous studies have shown that serum C-RP has increased up to 16 to 80 -fold [3] in five experimentally and 30-fold in two naturally infected dogs with leptospirosis [13]. The authors hypothesize that Leptospira strains may have different pathogenicity among studies, or that previous studies were conducted with small sample size.

Typical clinicopathological abnormalities in dogs with leptospirosis include leukocytosis; increased

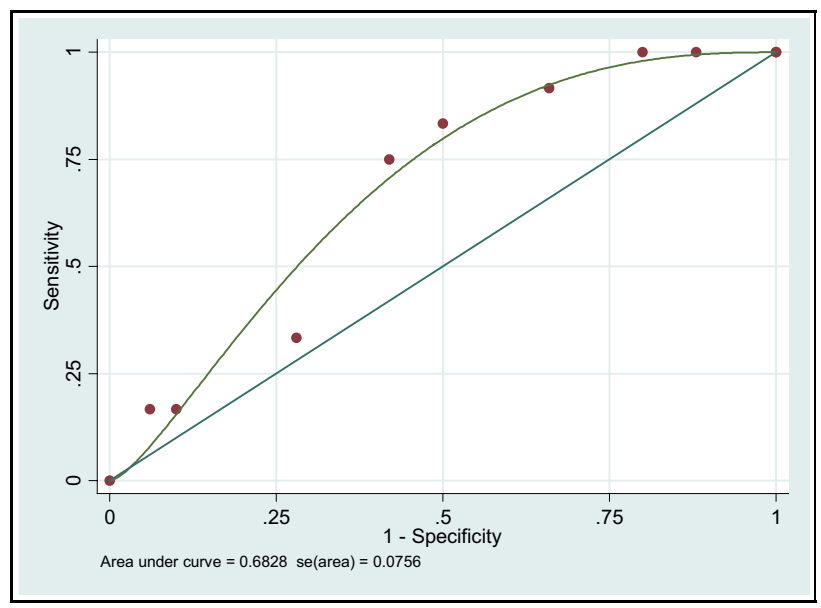

Figure 1. Fitted receiver operating characteristic (ROC) for the ability of serum C-PR to predict leptospiremia (positive blood PCR) in dogs, with confidence band. blood liver enzymes and bilirubinemia in cases of hepatic damage, and increased concentrations of blood urea and creatinine if renal insufficiency is present $[1,5,10]$. Decreased serum albumin levels and high creatine kinase levels are also common findings [8]. Albumin is a negative APP, and as C-RP, the change in its concentrations may occur in different inflammatory or infectious conditions. Thereby, the association between C-RP and albumin that occurred in the present study was expected, independent of the primary disease. Since association of C-RP with high levels of hepatic enzymes was weak, C-RP may be used as part of a screening profile, but not as indicator itself for either hepatic diseases of leptospiral infection.

\section{CONCLUSIONS}

Although C-RP may be used as part of a screening profile, it should not be an consider as indicator of leptospirosis alone screening in dogs, since no advantage was observed including C-RP as a screening test in dogs suspected of leptospirosis.

\section{SOURCES AND MANUFACTURERS}

${ }^{1}$ QIAamp DNA Blood Mini kit, QIAGEN, Valencia, CA, USA

${ }^{2}$ GoTaqFlexi DNA Polymerase, Promega, Madison, WI, USA ${ }^{3}$ Human GMBH, Max-Planck-Ring 21 D 65205 Wiesbaden, Germany.

${ }^{4}$ Metrolab 1600, Buenos Aires, Argentina

${ }^{5}$ Labtest, Lagoa Santa, MG, Brazil

${ }^{6}$ Celm CC 530, Barueri, SP, Brazil

Acknowledgments. The authors thank Irina Nastassja Riediger, Rafael Stedile, Vanessa Galimberti and Roger Halla for technical assistance and helpful suggestions. 


\section{REFERENCES}

1 Birnbaum N., Center S.A. \& Randolph J.F. 1998. Naturally acquired leptospirosis in 36 dogs: serological and clinicopathological features. Journal of Small Animal Practice. 39(5): 231-236.

2 Branger C., Blanchard B., Fillonneau C., Suard I., Aviat F., Chevallier B. \& André-Fontaine G. 2005. Polymerase chain reaction assay specific for pathogenic Leptospira based on the gene hapl encoding the hemolysis-associated protein-1. FEMS Microbiology Letters. 243(2): 437-445.

3 Caspi D., Snel F. W. J. J., Batt R. M., Bennett D., Rutterman G. R., Hartman E. G., Baltz M. L., Gruys E. \& Pepys M. B. 1987. C-reactive protein in dogs. American Journal of Veterinary Research. 48(6): 919-921.

4 Cerón J.J., Eckersall P.D. \& Martínez-Subiela S. 2005. Acute phase proteins in dogs and cats: current knowledge and future perspectives. Veterinary Clinical Pathology. 34(2): 85-99.

5 Gravekamp C., Van De Kemp H., Franzen M., Carrington D., Schoone G.J., Van Eys G.J.J.M., Everard C.O.R., Hartskeerl R.A. \& Terpstra W.J. 1993. Detection of seven species of pathogenic leptospires by PCR using two sets of primers. Journal of General Microbiology. 139(8): 1691-1700.

6 Greene C.E., Sykes J.E., Brown C.A. \& Hartmann K. 2006. Leptospirosis. In: Greene C.E. (Ed). Infectious Diseases of the Dog and Cat. 3rd edn. Philadelphia: Saunders Elsevier, pp.402-415.

7 Jabs W.J., Lögering B.A., Gerke P., Kreft B., Wolber E.M., Klinger M.H.F., Fricke L. \& Steinhoff J. 2003. The kidney as a second site of human C-reactive protein formation in vivo. European Journal of Immunology. 33(1): 152-161.

8 Langston C.E. \& Heuter K.J. 2003. Leptospirosis. A re-emerging zoonotic disease. Veterinary Clinics of North America: Small Animal Practice. 33(4): 791-807.

9 Lucchesi P.M.A., Arroyo G.H., Etcheverría A.I., Parma A.E. \& Seijo A.C. 2004. Recommendations for the detection of Leptospira in urine by PCR. Revista da Sociedade Brasileira de Medicina Tropical. 37(2): 131-134.

10 Sessions J.K. \& Greene C.E. 2004. Canine leptospirosis: epidemiology, pathogenesis, and diagnosis. Compendium on Continuing Education for the Practicing Veterinarian. 26 (8): 700-706.

11 Van de Maele I., Claus A., Haesebrouck F. \& Daminet S. 2008. Leptospirosis in dogs: a review with emphasis on clinical aspects. Veterinary Record. 163(14): 409-413.

12 VeigaA.P.M, Oliveira S.T., Esteves V., Portela V.M., SantosA.P. \& González F.H.D. 2009. Utilização de técnica rápida de aglutinação em látex para determinação semiquantitativa dos níveis séricos de proteína C reativa em cães. Acta Scientiae Veterinariae. 37(2): 151-155.

13 Yamamoto S., Shida T., Miyaji S., Santsuka H., Fujise H., Mukawa K., Furukawa E., Nagae T. \& Naiki M. 1993. Changes in serum C-reactive protein levels in dogs with various disorders and surgical traumas. Veterinary Research Communications. 17(2): 85-93. 